\title{
CORROSION EFFECT OF ANIMAL SLURRY ON LOW CARBON S235JR STEEL AT $333 \mathrm{~K}$
}

Tomasz LIPINSKI, Department of Material and Machine Technology, University of Warmia and Mazury in Olsztyn, Michała Oczapowskiego str. 2, Olsztyn, Poland, tomaszlipinski.tl@gmail.com

\begin{abstract}
Low-carbon steels are often used for materials in the construction of machines and equipment for agricultural. One of the most important factors constructional material is corrosion resistance, first of all in demanding animal environment. Equipment with low carbon steel can be easy join by quickly welding at a low construction price, but one with the serious problem in aggressive environment is their corrosion resistance.

A few corrosion processes in crevices and awkward corners can be avoided at the design stage (low roughness parameters, roundsection and other). But still the construction material is exposed to corrosion.

Slurry is a mixture of dung and urine. The aggressive corrosive constituents in slurry are urea, uric acid, naturally excreted chloride and as well as ammonia or ammonium salts.

The main aim of this research is to investigate corrosion resistance in different time (48, 96, 144, 192, 240, 288,336 hours). For this used weight loss of test samples and its profile roughness. The research was conducted on low carbon steel in grade S235JR in natural animal slurry at $333 \mathrm{~K}$.

Corrosion tests confirmed that the research this steel in animal slurry as corrosive environments is characterized through proportionate to time corrosion process whose measure may be surface roughness. In industrial practice roughness parameters for all the research times can be used for determine the stage and size of steel corrosion.
\end{abstract}

Keywords: Animal slurry, carbon steel, corrosion, corrosion rate, roughness

\section{INTRODUCTION}

Carbon steel is one of the most popular materials in the construction of machines and equipment for agricultural because is cheaper then more resistance but expensive stainless steel (Dudek et al., 2014; Lipiński, 2016b; Sha and Yang, 2016). The S235JR low carbon steel is commonly used for agricultural industry. The properties constructional steel are determined mostly by their microstructure and production technology (Lipinski and Wach 2015, Nová and Machuta 2016; Szabracki and Lipiński, 2013; Ulewicz, 2003; Włodarczyk et al., 2011). Apart of this negative corrosion effect have mostly other metals inclusions which are dependent on their shape, numbers, size and distribution (Szabracki and Lipiński, 2014). The accumulation of chemical elements with animal slurry near steel is the primary cause of corrosion. The results of corrosion of low carbon steel in machines and equipment for agriculture are geometry change can cause construction cracking, building up and increments of corrosion products what can caused to withstand load effects of constructions materials (Duryahina etal., 2007; Luu et al., 2011; Mahdi et al., 2014; De Belie et al., 2000; Pitrmuc et al., 2016). Usually corrosion of carbon steel was identified during the maintenance process. Unfortunately, corrosive processes of carbon steel can cause different forms of corrosion. Many research are conducted to evaluate the performance of carbon and stainless steel microstructures under a variety of corrosive conditions (Kusmic and Van Than, 2017; Lipiński, 2015, 2016b; Pilch et al., 2017; Scendo et al., 2013; Selejdak et al., 2014; Szabracki and Lipiński, 2014).

The wide variety of agricultural employed makes difficult to define where corrosion can be a little or most damaging. Corrosion in agricultural industry is also influenced by animal slurry and its products that have passed into the atmosphere such as chlorides vapors, NOx and SOy, HzS and other. Penetration corrosion processes of low carbon steel with animal products are very aggressive (Aguirre and Walczak, 1017; Song and Du, 2017; Tang et al., 2008, Yang and Cheng, 2011; Zatkalíková et al., 2016). Slurry is a mixture of dung and urine, and farmyard manure and etc. The corrosive constituents in slurry are firs of all: ammonia and its salts, urea, uric acid, naturally excreted chloride. Consequence influence corrosion processes during the maintenance low carbon steel with animal slurry atmosphere can be atmosphere corrosion effect, too (Naz et al., 2017; Uhlig and Revie, 1985; Yang and Cheng, 2012; Yu et al., 2013).

The animal slurry is important corrosive environmental factors in agricultural industry. Having regard to the importance of the corrosion resistance for exploitation, this research was carried out to determination the corrosion

Copyright (C) 2017 The Authors. Published by Aleksandras Stulginskis University. This is an open-access article distributed under the terms of the Creative Commons Attribution License (CC-BY 4.0), which permits unrestricted use, distribution, and reproduction in any medium, provided the original author and source are credited. 
resistance of low carbon structural steel in animal slurry. For intensification the corrosion process the samples was tested at temperature $333 \mathrm{~K}$.

\section{MATERIALS AND METHODS}

The research was performed on low carbon commercial S235JR (1.0038) steel plate $t=5.00$ mm thickness with chemical composition according to the EN 10025-2:2004 (EN 2004). The chemical composition of the tested steel is presented in Table 1 (Lipiński 2017a, 2017b).

Table 1. Real chemical composition of the commercial S235JR steel

\begin{tabular}{|c|c|c|c|c|c|c|c|c|}
\hline \multicolumn{10}{|c|}{ Mean chemical compositions [wt. \%] } \\
\hline $\mathrm{C}$ & $\mathrm{Si}$ & $\mathrm{Mn}$ & $\mathrm{P}$ & $\mathrm{S}$ & $\mathrm{Cr}$ & $\mathrm{Cu}$ & $\mathrm{Ni}$ & $\mathrm{N}$ \\
\hline 0.19 & 0.22 & 0.90 & 0.03 & 0.04 & 0.03 & 0.02 & 0.02 & 0.01 \\
\hline
\end{tabular}

Average mechanical properties of the S235JR steel at ambient temperature according to the standard EN 100252:2004 are presented in Table 2.

The specimens from plate $\mathrm{t}=5.00 \mathrm{~mm}$ thickness was cut mechanically samples to size $40 \times 10 \mathrm{~mm}$ (area of 13 $\mathrm{cm} 2$ ). Next the samples were polished with water paper successively to $\mathrm{R}_{\mathrm{a}}=0.32 \mu \mathrm{m}$, and cleaned by $95 \% \mathrm{C}_{2} \mathrm{H}_{5} \mathrm{OH}$.

The samples prepared by sanding and degreasing with ferritic-perlitic microstructure were tested on the basis of corrosion guidelines for stainless steel accordance with the standard EN ISO 3651-1:2002 (EN 2002). The application of the criteria provided for stainless steel was intended to enable comparative assessment of the corrosion resistance of carbon steel and stainless steel in the future. Animal slurry mean chemical compositions as a corrosive media were represented in Table 3 and its parameters in Table 4. The corrosion resistance steel was tested by measurement of loss in mass (Huey test).

Table 3. Mean chemical compositions animal slurry

\begin{tabular}{|c|c|c|c|c|c|c|c|}
\hline \multicolumn{7}{|c|}{ Chemical composition of animal slurry } \\
\hline $\mathrm{P}$ & $\mathrm{K}$ & $\mathrm{Mg}$ & $\mathrm{Ca}$ & $\mathrm{Na}$ & $\mathrm{Cu}$ & $\mathrm{Zn}$ & $\mathrm{NO}_{3}$ \\
\hline $\mathrm{mg} / \mathrm{L}$ & $\mathrm{mg} / \mathrm{L}$ & $\mathrm{mg} / \mathrm{L}$ & $\mathrm{mg} / \mathrm{L}$ & $\mathrm{mg} / \mathrm{L}$ & $\mathrm{mg} / \mathrm{L}$ & $\mathrm{mg} / \mathrm{L}$ & $\mathrm{mg} / \mathrm{L}$ \\
\hline 175 & 158 & 6,4 & 39,2 & 102 & 0,08 & 0,41 & 35 \\
\hline
\end{tabular}

Table 4. Parameters of animal slurry

\begin{tabular}{|c|c|c|c|c|}
\hline $\mathrm{PH}$ & $\mathrm{EC}$ & $\mathrm{BOD}$ & $\mathrm{COD}$ & $\mathrm{TKN}$ \\
\hline & $\mathrm{mS} / \mathrm{cm}^{2}$ & $\mathrm{mg} / \mathrm{L}$ & $\mathrm{mg} / \mathrm{L}$ & $\mathrm{g} / \mathrm{L}$ \\
\hline 6,7 & 5,86 & 2350 & 2980 & 1,82 \\
\hline
\end{tabular}

EC - electric conductivity, BOD Biochemical oxygen demand, COD - chemical oxygen demand, TKN - Total Kjeldohl nitrogen

The corrosion rate samples performed from plate of S235JR steel was calculated in mm per year accordance to formula (1) and calculated in grams per square meter accordance to formula (2):

$$
\begin{aligned}
& r_{\text {corm }}=\frac{8760 \cdot m}{S \cdot t \cdot \rho} \\
& r_{\text {corg }}=\frac{10000 \cdot m}{s \cdot t}
\end{aligned}
$$

where:

$\mathrm{t}$ - time of soaking in a corrosive solution of animal slurry on temperature $33 \mathrm{~K}$ [hours],

$\mathrm{S}$ - contact surface of the sample with corrosive solution of the sample $\left[\mathrm{cm}^{2}\right]$,

$\mathrm{m}$ - average mass loss after the test in animal slurry $[\mathrm{g}]$,

$\rho$ - tabular density of the sample $\left[\mathrm{g} / \mathrm{cm}^{3}\right]$.

The corrosion rate in animal slurry the S235JR carbon steel was investigated using weight loss after the test in animal slurry. The mass of samples for every testing time were measured by Kern ALT 3104AM laboratory precision balance. The accuracy of measurement was $0.0001 \mathrm{~g}$. The time range of research was: 48, 96, 144, 192, 240, 288, 336, 384 and 432 hours.

Surface roughness measurement were analyzed according to the EN 10049:2013 standard by the Diavite DH5 profilometer.

\section{RESULTS AND DISCUSSION}

The microstructure the S235JR steel before the corrosion process is presented at Fig. 1 - clearly visible the effect of manufacturing process this steel on the miceostructure as an elongated white ferrite phase and the dark perlite phase. Surface the test samples after corrosion tests in animal slurry at $333 \mathrm{~K}$ temperature for time 240 hours is presented at Fig. 2. 


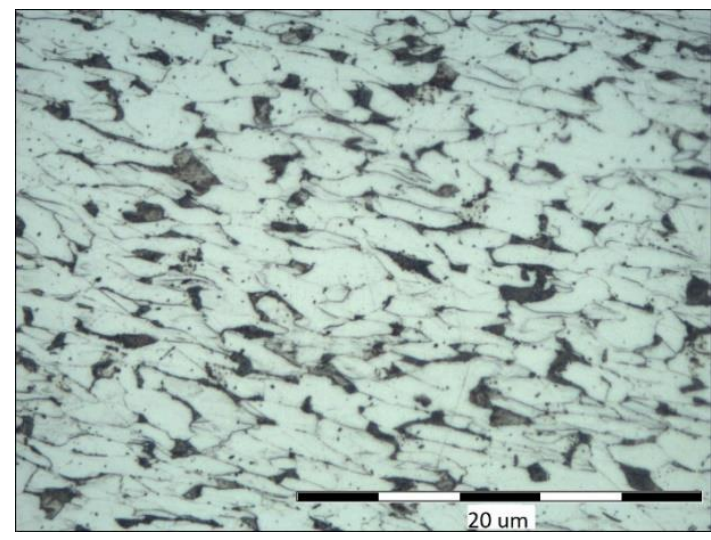

Figure 1. Microstructure of S235JR steel before corrosion testing: light ferrite and dark perlite

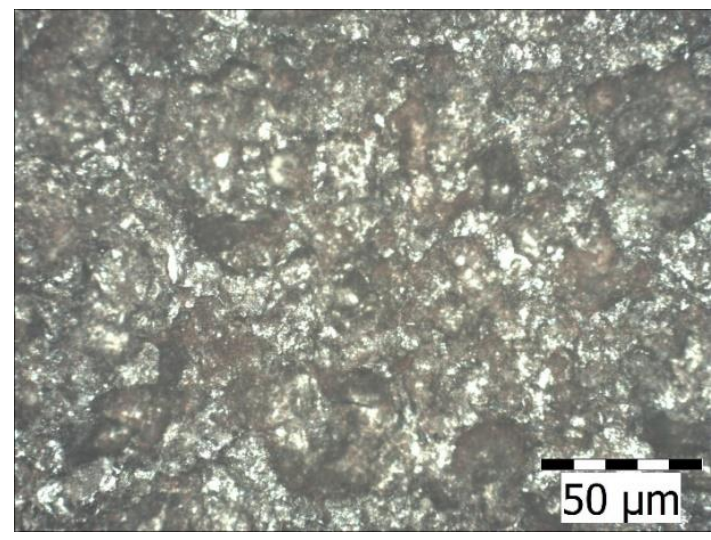

Figure 2. Surface of S235JR steel after corrosion tests in animal slurry at $333 \mathrm{~K}$ temperature for time 240 hours

Profile roughness parameters of S235JR steel after corrosion tests in animal slurry at temperature $333 \mathrm{~K}$ for 96 hours is presented in Fig. 3, for 240 hours in Fig. 4 and for 432 hours in Fig. 5. The roughness profile of S235JR steel with: $R_{a}$ - arithmetical mean roughness value $[\mu \mathrm{m}], \mathrm{R}_{\mathrm{p}}$ - maximum roughness depth $[\mu \mathrm{m}], \mathrm{R}_{\mathrm{q}}$ - mean peak width $[\mu \mathrm{m}], \mathrm{R}_{\mathrm{t}}-$ total hight of the roughness profile $[\mu \mathrm{m}]$ for different corrosion time is presented in Fig. 6 for $R_{a}$ and $R_{q}$ and in Fig. 7 for $R_{t}$ and $R_{p}$. Regression equation of the roughness and $r$ as its correlation coefficient is presented in (3) - (6), where t-parameter is time in hours.

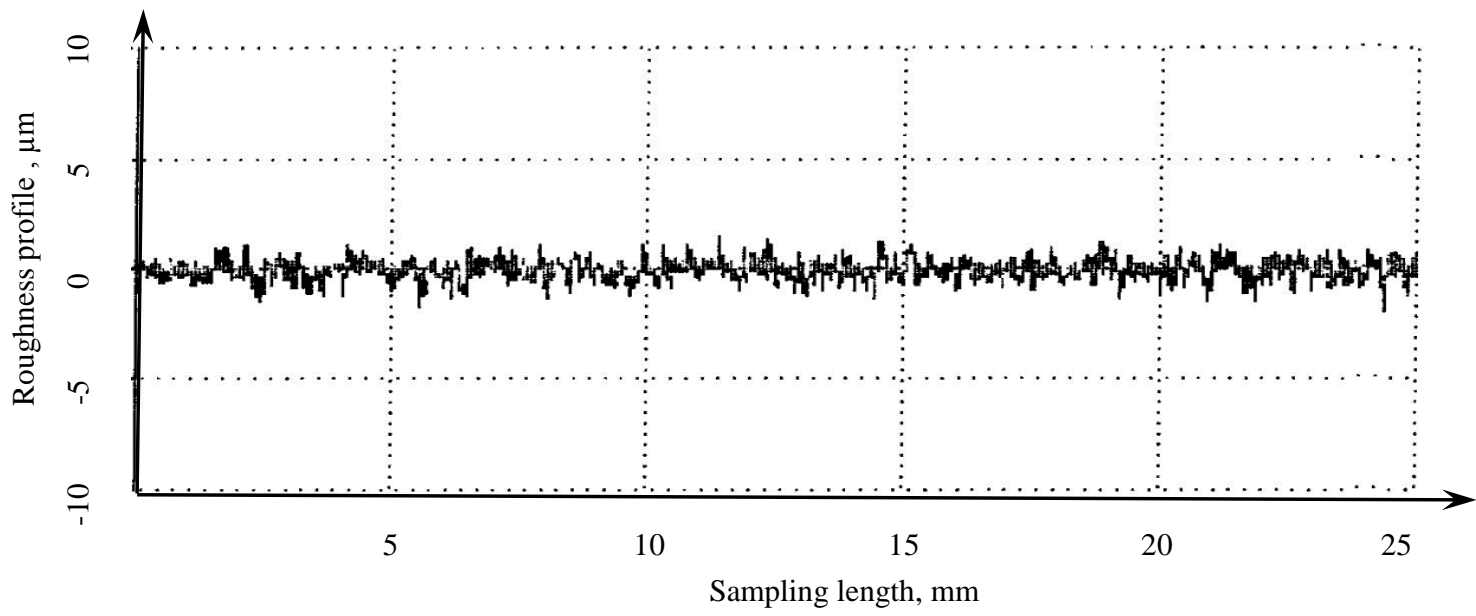

Figure 3. The roughness profile of S235JR steel after 96 hours corrosion tests in animal slurry at temperature $333 \mathrm{~K}$

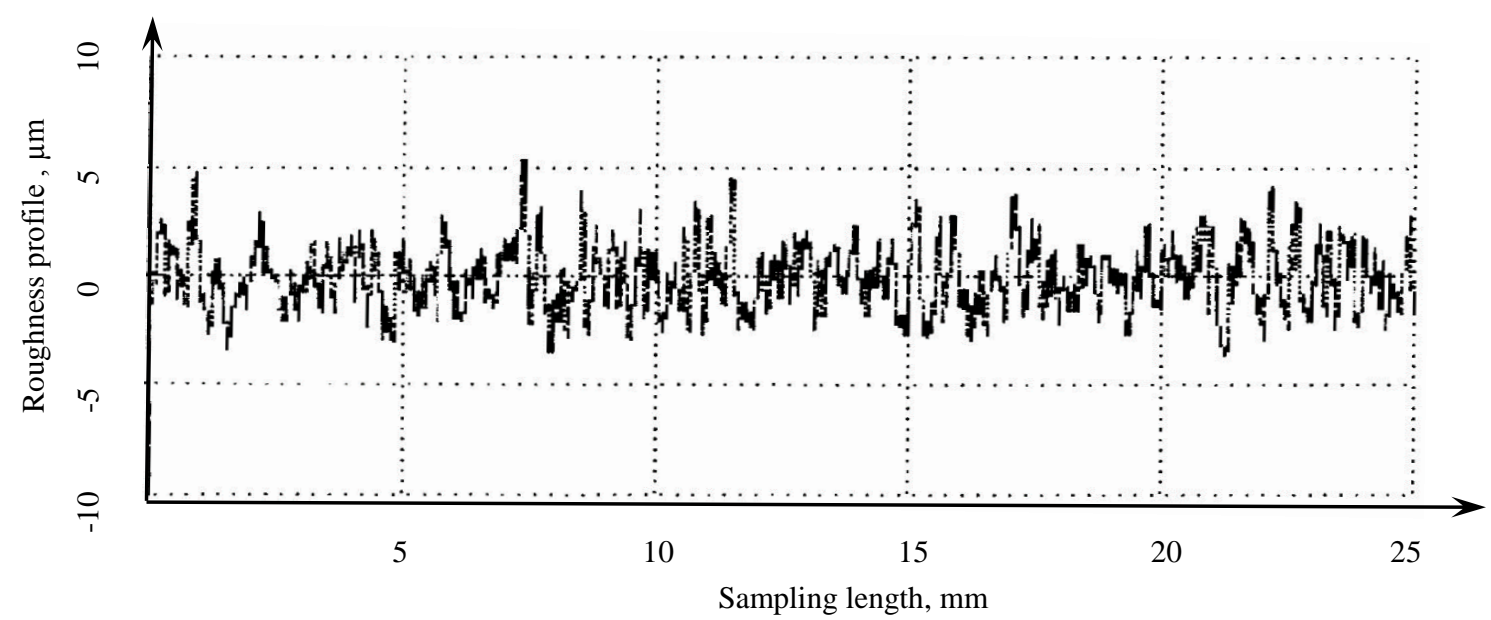

Figure 4. The roughness profile of S235JR low carbon steel after 240 hours corrosion tests in animal slurry at temperature $333 \mathrm{~K}$ 


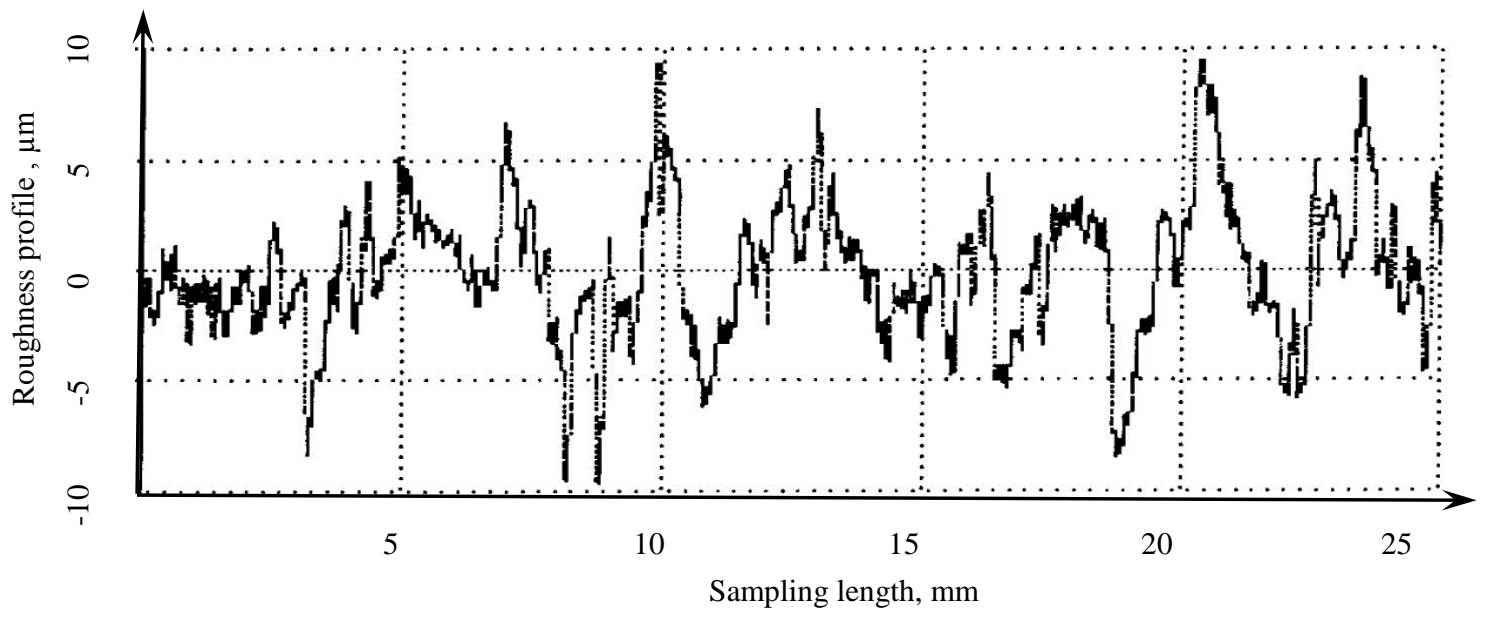

Figure 5. The roughness profile of S235JR low carbon steel after 432 hours corrosion tests in animal slurry at temperature $333 \mathrm{~K}$

$$
\begin{aligned}
& R_{a}=5 \cdot 10^{-6} t^{2}+0.0034 \cdot t+0.0188 \text { and } \mathrm{r}=0.9984 \\
R_{q}= & 9 \cdot 10^{-6} t^{2}+0.0035 \cdot t+0.0321 \text { and } \mathrm{r}=0.995 \\
& R_{t}=4 \cdot 10^{-5} \cdot t^{2}+0.0256 \cdot t+0.0321 \text { and } \mathrm{r}=0.995 \\
R_{p}= & 6 \cdot 10^{-5} \cdot t^{2}+0.0145 \cdot t+1.45 \text { and } \mathrm{r}=0.9966
\end{aligned}
$$

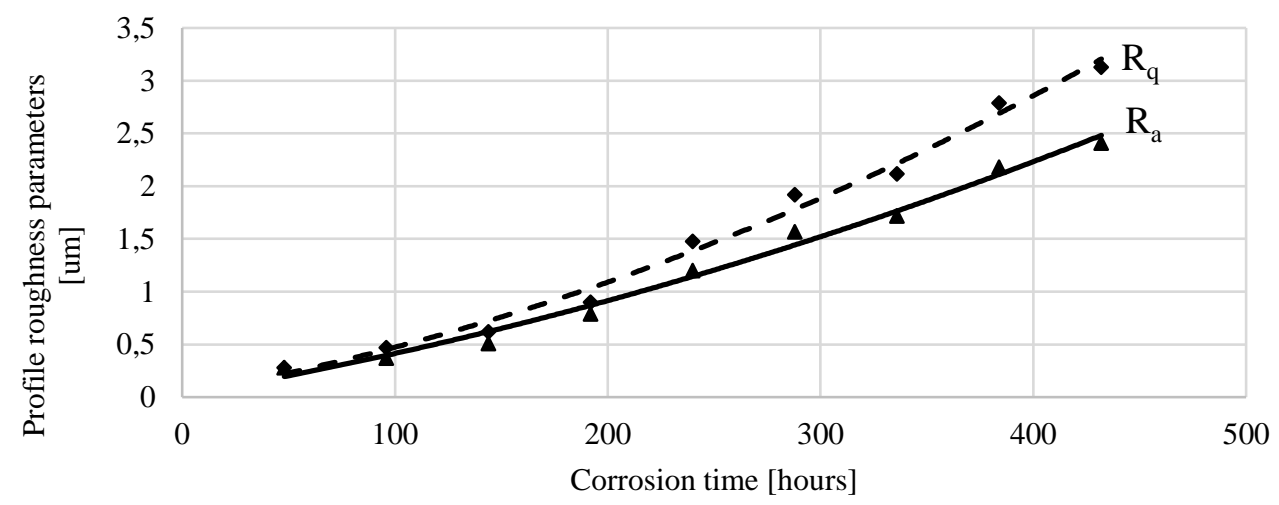

Figure 6. Roughness of S235JR low carbon steel after different time corrosion tests in animal slurry at temperature $333 \mathrm{~K}: R a-$ arithmetical mean roughness value $(\mu \mathrm{m}) ; R q$ - mean peak width $(\mu \mathrm{m})$

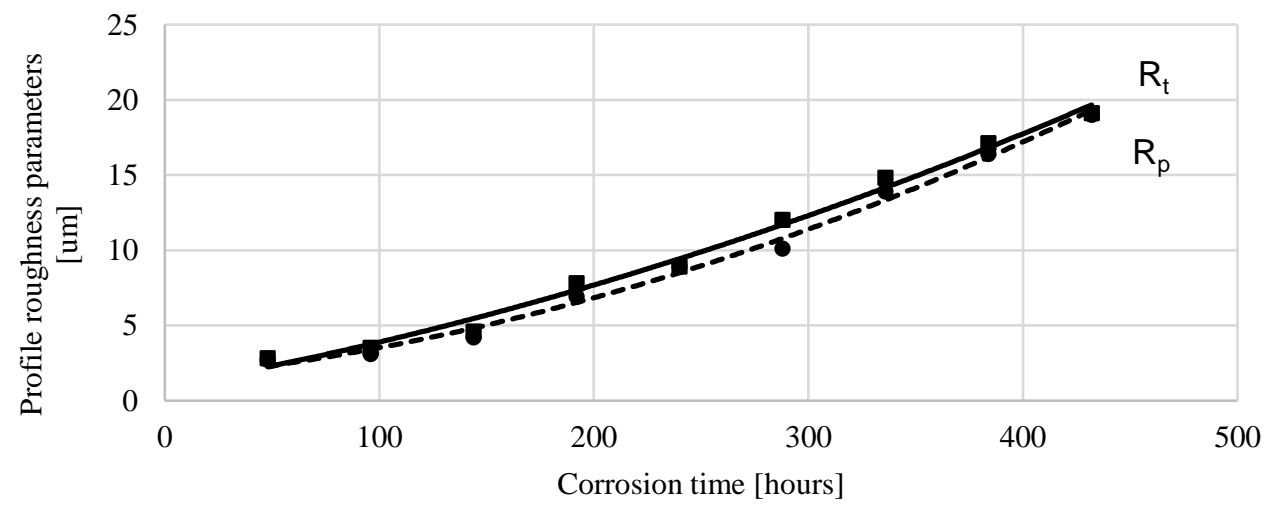

Figure 7. Roughness of S235JR steel after different time corrosion tests in animal slurry at temperature $333 \mathrm{~K}: R p$ - maximum roughness depth $(\mu \mathrm{m}) ; R t-$ total height of the roughness profile $(\mu \mathrm{m})$

The influence of the testing time the S235JR low carbon steel in animal slurry at temperature $333 \mathrm{~K}$ on the relative mass loss (RML) is presented in Fig. 8. The regression equation and $\mathrm{r}$ as its correlation coefficient is presented at (7). 


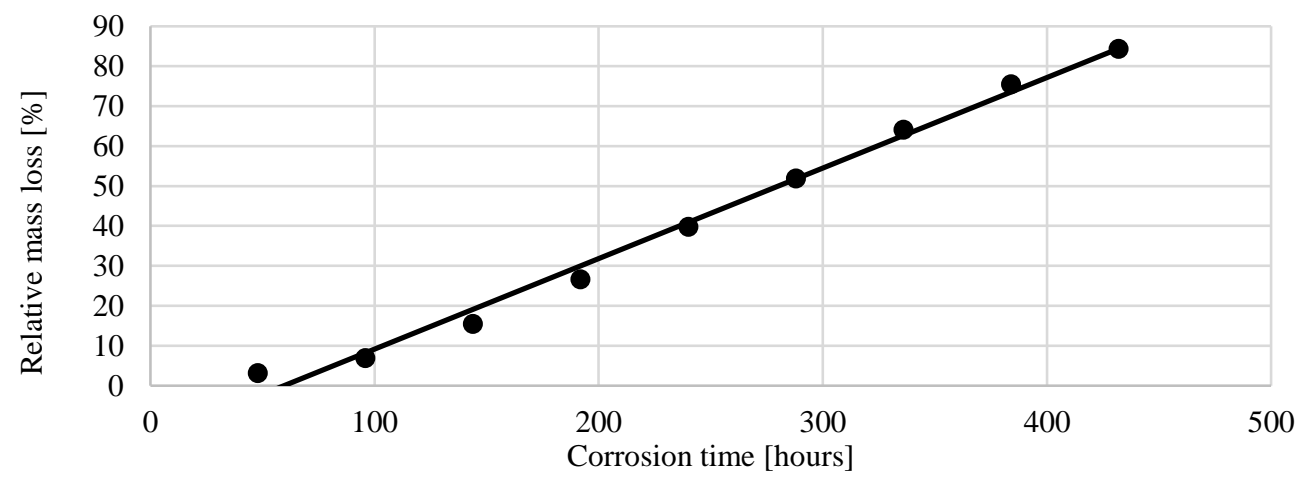

Figure 8. Relative mass loss (RML) the S235JR low carbon steel as a function corrosion time in animal slurry at temperature $333 \mathrm{~K}$

$$
R M L=0.2267 \cdot t+13.506 \text { and } \mathrm{r}=0.9953
$$

The corrosion rate S235JR low carbon steel calculated in mm per year after corrosion tests in animal slurry at temperature $333 \mathrm{~K}$ is presented in Fig. 9. The regression equation of corrosion rate rcorm and $\mathrm{r}$ as its correlation coefficient is presented at (8).

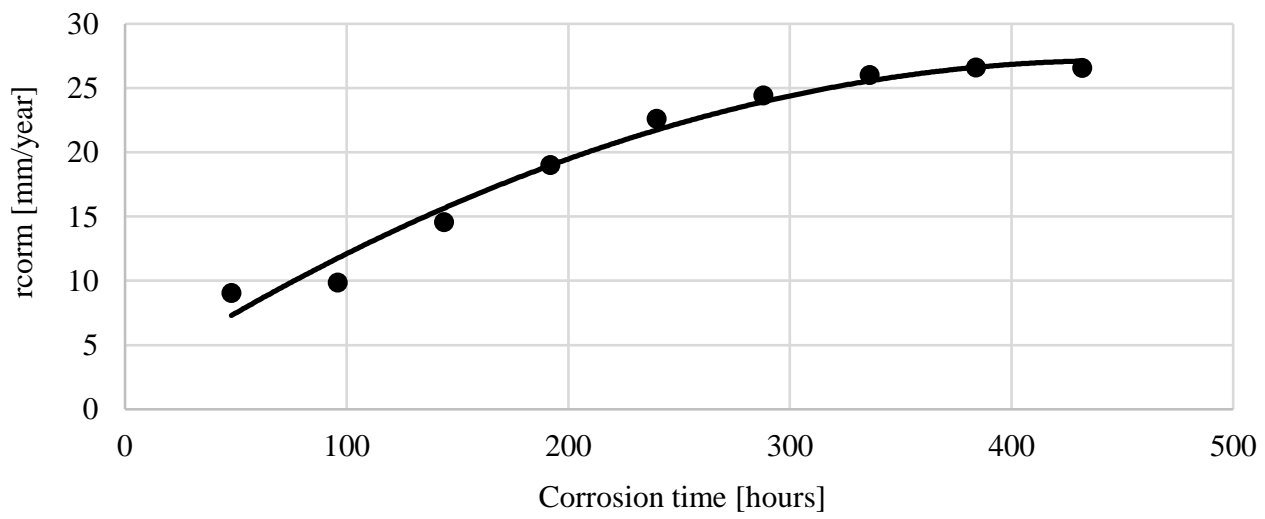

Figure 9. Corrosion rate measured in mm per year of S235JR steel after corrosion tests in different time with animal slurry at temperature $333 \mathrm{~K}$

$$
r_{\text {corm }}=-0.0001 \cdot t^{2}+0.1107 \cdot t+2.2683 \text { and } \mathrm{r}=0.9884
$$

The corrosion rate S235JR low carbon steel calculated in g per square meter after corrosion tests in animal slurry at temperature $333 \mathrm{~K}$ is presented in Fig. 10. The regression equation of corrosion rate rcorg and $\mathrm{r}$ as its correlation coefficient is presented at (9).

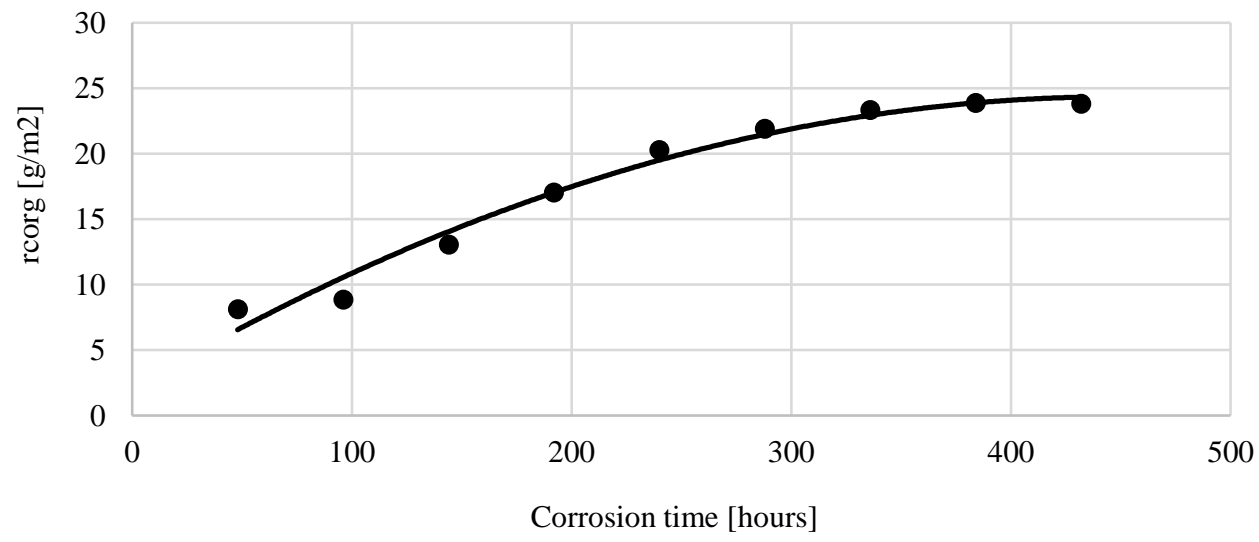

Figure 10. Corrosion rate measured in mm per square meter of S235JR steel after corrosion tests in different time with animal slurry at temperature $333 \mathrm{~K}$

$$
r_{\text {corg }}=0.6938 \cdot t^{-0.24} \text { and } \mathrm{r}=0.9624
$$

The microstructure of steel are with the corrosion time. 
The surface of the S235JR carbon steel increases its cropacity along with the prolongation of the animal slurry as a corrosive medium's exposure time. The steel microstructure after 336 hours of soaking in animal slurry at temperature $333 \mathrm{~K}$ is shown in Fig. 11.

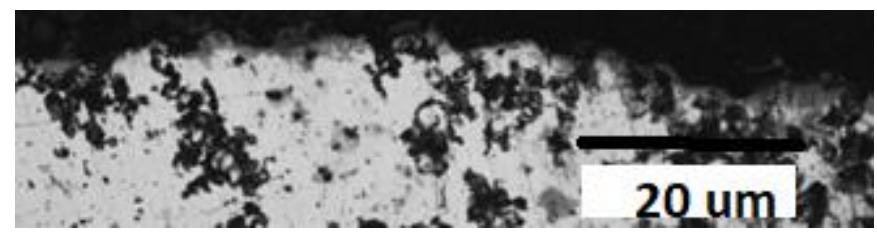

Figure 11. The microstructure of S235JR steel after corrosion tests with animal slurry at temperature $333 \mathrm{~K}$

\section{CONCLUSIONS}

- The animal slurry is one of the most aggressive corrosion factors in agricultural industry. To establish the properties of S235JR steel degradation in animal slurry environments tested at $333 \mathrm{~K}$ is determining the change in the roughness parameters and corrosion resistance. Of course the high temperature was use to increase corrosion rate.

- Corrosion tests in animal slurry at temperature $333 \mathrm{~K}$ is sensible to the time of corrosion process.

- Good regression coefficients were obtained for the linear regression equation considered for all the tested parameters.

- The mass loss is good indicator corrosion process. By using equations describing material roughness or corrosion rate, it is possible to determine conditions for simply control of the condition of an agricultural object.

\section{REFERENCES}

1. Aguirre, J., Walczak, M. 2017. Effect of dissolved copper ions on erosion-corrosion synergy of X65 steel in simulated copper tailing slurry. Tribology International, Vol. 114, pp. 329-336. https://doi.org/10.1016/j.triboint.2017.04.036

2. De Belie, N., Sonck, B., Braam, C.R., Lenehand, J.J., Svennerstedte B., Richardson M. 2000. Durability of building materials and components in the agricultural environment, Part II: metal structures. Journal of Agricultural Engineering Research, Vol. 75, pp. 333-347. https://doi.org/10.1006/jaer.1999.0521

3. Dudek, A., Wrońska, A., Adamczyk, L. 2014. Surface remelting of 316 L+434 L sintered steel: microstructure and corrosion resistance. Journal Solid State Electronics, Vol. 18, Iss. 11, pp. 2973-2981. https://doi.org/10.1007/s10008-014-2483-2

4. Duryahina, Z.A., Makhorkin, I.M., Lazko, H.V., Bychyns'kyi, V.I. 2007. Evaluation of temperature fields in corrosion-resistant steels under the action of laser radiation. Materials Science, Vol. 43, Iss. 6, pp. 800-806. https://doi.org/10.1007/s11003-008$\underline{9025-\mathrm{y}}$

5. EN 10025-2:2004. Hot rolled products of structural steels - Part 2: Technical delivery conditions for non-alloy structural steel.

6. EN 10049:2013. Measurement of roughness average Ra and peak count RPc on metallic flat products.

7. EN ISO 3651-1:2002. Determination of resistance to intergranular corrosion of stainless steels. Part 1: Austenitic and ferriticaustenitic (duplex) stainless steels. Corrosion test in nitric acid mediummby measurement of loss in mass (Huey test).

8. Kusmic, D., Van Than, D. 2017. Corrosion Resistance of Plasma Nitrided and Nitrocarburized 42CrMo4 Steel. Manufacturing Technology, Vol. 17, Iss. 2, pp. 211-217.

9. Lipiński, T. 2015. Corrosion Rate of the X2CrNiMoN22-5-3 Duplex Stainless Steel Annealed at 500 degrees C. Acta Physica Polonica, A 130 (4), 993-995. https://doi.org/10.12693/APhysPolA.130.993

10. Lipiński, T. 2016a. Corrosion of X2CrNiMoSi18-5-3 Duplex Stainless Steel. Proceedings of 15 International Scientific Conference Engineering for Rural Developments, Vol. 15, pp. 946-951.

11. Lipiński, T. 2016b. Corrosion Resistance of 1.4362 Steel in Boiling 65\% Nitric Acid. Manufacturing Technology, Vol. 16, Iss. 5, pp. 1004-1009.

12. Lipiński, T. 2017a. Corrosion Effect of $20 \% \mathrm{NaCl}$ Solution on Basic Carbon Structural S235JR Steel. Proceedings of 15 International Scientific Conference Engineering for Rural Developments, Vol. 15, pp. $1069-1074$. https://doi.org/10.22616/ERDev2017.16.N225

13. Lipiński, T. 2017b. Corrosion of S235JR Steel in $\mathrm{NaCl}$ Environment at $3{ }^{\circ} \mathrm{C}$. METAL 2017: 23rd International Conference on Metallurgy and Materials. Ostrava TANGER.

14. Lipiński, T., Wach, A. 2015. The Effect of Fine Non-Metallic Inclusions on The Fatigue Strength of Structural Steel. Archives of Metallurgy and Materials, Vol. 60, Iss. 1, pp. 65-69. https://doi.org/10.1515/amm-2015-0010

15. Lu B.T. , Lu J.F., Luo J.L. 2011. Erosion-corrosion of carbon steel in simulated tailing slurries. Corrosion Science. Vol. 53, pp. 1000-1008. https://doi.org/10.1016/j.corsci.2010.11.034

16. Mahdi, E., Rauf, A., Eltai E.O. 2014. Effect of temperature and erosion on pitting corrosion of X100 steel in aqueous silica slurries containing bicarbonate and chloride content. Corrosion Science, Vol. 83, pp. 48-58. https://doi.org/10.1016/j.corsci.2014.01.021

17. Naz, M.Y., Sulaiman, S.A., Shukrullah, S., Ghaffar, A., Ibrahim, K.A., AbdEl-Salam, N.M. 2017. Development of erosioncorrosion mechanisms for the study of steel surface behavior in a sand slurry. Measurement, Vol. 106, pp. $203-210$. https://doi.org/10.1016/j.measurement.2017.04.042 
18. Nová, I., Machuta, J. 2016. Monitoring of the Diffusion Processes during Carburizing Automotive Steel Parts. Manufacturing Technology, Vol. 16, Iss. 1, pp. 225-230.

19. Pilch, O., Faltejsek, P., Hrubý, V., Krbat'a, M. 2017. The Corrosion Resistance of Turbocharger Stator after Plasma Nitriding Process. Manufacturing Technology, Vol. 17, Iss. 3, pp. 360-364.

20. Pitrmuc, Z., Capek, J., Kolarik, K., Beranek, L., Urban, J. 2016. Tool Geometry Influence on Surface Integrity of Machined Austenite Stainless Steel. Manufacturing Technology, Vol. 16, Iss. 2, pp. 425-431.

21. Scendo, M., Radek, N., Trela, J. 2013. Influence of laser treatment on the corrosive resistance of Wc-Cu coating produced by electrospark deposition. International Journal Electrochemical Sciences, Vol. 8, pp. 9264-9277.

22. Selejdak, J., Ulewicz, R., Ingaldi, M. 2014. The evaluation of the use of a device for producing metal elements applied in civil engineering. 23rd International Conference on Metallurgy and Materials METAL, pp. 1882-1888.

23. Sha, Liu, Yang, X., 2016. The Parametric Design of the Frame of Agricultural Machinery Cab based on Analysis of Ergonomics. Manufacturing Technology, Vol. 16, Iss. 3, pp. 543-551.

24. Song, F. G., Du, L.G. 2017. Erosion corrosion of low-alloy wear-resistant steels in alkaline slurry. Journal of Ironand Steel Research, International Vol. 24, pp. 1065-1072. https://doi.org/10.1016/S1006-706X(17)30154-1

25. Szabracki, P., Jaskólski M., Lipiński T., Kaczmarek-Kacprzak A. 2014. The FEM analysis of pressure installation elements after simulated accidental overheating. Recent Advances in Computational Mechanics, pp. 311-317. CRC Press Taylor \& Francis Group A Balkema Book London.

26. Szabracki, P., Lipiński, T. 2013. Effect of aging on the microstructure and the intergranular corrosion resistance of X2CrNiMoN257-4 duplex stainless steel. Solid State Phenomena, Vol. 203-204, pp. 59-62. https://doi.org/10.4028/www.scientific.net/SSP.203$\underline{204.59}$

27. Szabracki, P., Lipiński, T. 2014. Influence of sigma phase precipitation on the intergranular corrosion resistance of X2CrNiMoN257-4 super duplex stainless steel. 23rd International Conference on Metallurgy and Materials METAL, pp. 476-481.

28. Tang X., Xu L.Y., Cheng Y.F. 2008. Electrochemical corrosion behavior of X-65 steel in the simulated oil-sand slurry. II: Synergism of erosion and corrosion. Corrosion Science, Vol. 50, pp. 1469-1474. https://doi.org/10.1016/j.corsci.2008.01.019

29. Uhlig, H.H., Revie, R.W. 1985. Corrosion and corrosion control, 3rd Edition, John Wiley and Sons.

30. Ulewicz, R. 2003. Quality control system in production of the castings from spheroid cast iron. Metalurgija 42(1), 61-63.

31. Włodarczyk, R., Dudek, A., Nitkiewicz, Z. 2011. Corrosion analysis of sintered material used for low-temperature fuel cell plates. Archives of Metallurgy and Materials, Vol. 59, Iss. 1, pp. 135-140. https://doi.org/10.2478/v10172-011-0021-0

32. Yang, Y., Cheng, Y.F. 2011. Electrolytic deposition of Ni-Co-SiC nano-coating for erosion-enhanced corrosion of carbon steel pipes in oilsand slurry. Surface \& Coatings Technology, Vol. 205, pp. 3198-3204. https://doi.org/10.1016/j.surfcoat.2010.11.035

33. Yang, Y., Cheng, Y.F. 2012. Parametric effects on the erosion-corrosion rate and mechanism of carbon steel pipes in oil sands slurry. Wear, Vol. 276-277, pp. 141- 148.

34. Yu, B., Li, D.Y., Grondin, A. 2013. Effects of the dissolved oxygen and slurry velocity on erosion-corrosion of carbon steel in aqueous slurries with carbon dioxide and silica sand. Wear, Vol. 302, pp. 1609-1614. https://doi.org/10.1016/j.wear.2013.01.044

35. Zatkalíková V., Markovičová L., Chalupova M. 2016. Corrosion resistance of Cr-Ni-Mo Stainless Steel in Chloride and Fluoride Containing Environment. Manufacturing Technology, Vol. 16, Iss. 5, pp. 1193-1198. 